\title{
Indolbutyric Acid (IBA) in the African Mahogany (Khaya grandifoliola C. DC.) cuttings and mini-cuttings development
}

\author{
Marília Gabriela da Silva ${ }^{1}$; Úrsula R. Zaidan $\oplus^{2}$; Canrobert T. Borges ${ }^{3}$; João Augusto da Silva ${ }^{3}$; \\ Rafael T. Resende $\mathbb{(}^{4}$; Fábio Venturoli ${ }^{1}$; Patrícia P. Pires $\mathbb{1}^{l}$
}

\author{
${ }^{1}$ Universidade Federal de Goiás, Escola de Agronomia/Engenharia Florestal, Av. Nerópolis s/n, CEP: 74.690-900, Goiânia - GO, Brazil \\ ${ }^{2}$ Universidade Federal de Viçosa, Departamento de Fitotecnia, Av. PH Rolfs, CEP: 36.570-900, Viçosa - MG, Brazil \\ ${ }^{3}$ Viveiro Mudas Nobres, Rod. GO-010, Km 6.5, s/n Zona Rural, 74.250-000, CEP: 74.250-000, Goiânia - GO, Brazil \\ ${ }^{4}$ Universidade Federal de Goiás, Escola de Agronomia/Melhoramento de Plantas, Av. Nerópolis s/n, CEP: 74.690-900, Goiânia - GO, Brazil
}

\section{Original Article \\ *Corresponding author: ursula.zaidan@gmail.com}

Keywords:

Vegetative propagation

Plant sprouts

Rooting

Modeling

Artificial intelligence

Palavras-chave:

Propagação vegetativa

Brotações

Enraizamento

Modelagem

Inteligência Artificial

Received in

2020/02/07

Accepted on

2020/04/11

Published in

2020/06/30

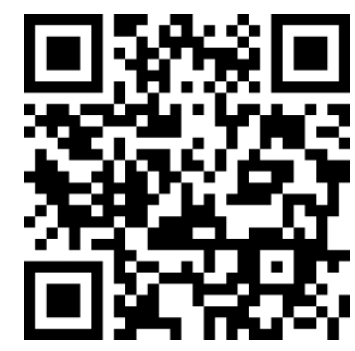

DOI:

https://doi.org/10.34062/afs. v7i2.9793

\section{(cc) BY}

ABSTRACT: The current expansion of the forest sector in the Cerrado (Brazilian Savannah), especially of the species of genus Khaya sp. (African Mahogany), requires several silvicultural and technical studies of various natures. Seed and clonal propagation enable noble and vigorous seedlings, which will future compose commercial plantations aiming timber production. The species Khaya grandifoliola C. DC is considered of distinct wood features and with great economic potential. The objective of this work was to evaluate the effect of different indolbultyric acid (IBA) concentrations - between 0 and 12 g.L $\mathrm{L}^{-1}-$ on the rooting of $K$. grandifoliola cuttings (clonal origin) and mini-cuttings (seed origin). The experiment was carried out at the "Mudas Nobres" private nursery, located in Goiânia (Goiás State, Brazil). The experiment was conducted in a completely randomized design in a $5 \times 2$ factorial scheme. Multivariate, Neural Networks and Random Forest models were also applied to estimate the number of shoots in clonal cuttings, according to the data observed in seed mini-cuttings. The results indicate that IBA has the opposite effect on the two evaluated types of propagule origin, being more suitable for seed mini-cuttings (should apply 8 g.L. L $^{-1}$ of IBA) and less suitable for clonal cuttings (should not apply IBA). In the operational nursery routine, if a standard application must be recommended (to cuttings either mini-cuttings), the most appropriate concentration is 6 g. $\mathrm{L}^{-1}$ of IBA.

RESUMO: A corrente expansão do setor florestal no Cerrado (savana brasileira), em especial das espécies do gênero Khaya (mogno africano), requer estudos técnicos silviculturais de diversas naturezas. A propagação seminal e clonal viabiliza mudas nobres e vigorosas, que irão compor os plantios comerciais visando a produtividade de madeira. A espécie Khaya grandifoliola C. DC. é considerada de madeira distinta e de grande potencial econômico. O objetivo deste trabalho foi avaliar o efeito de diferentes concentrações de ácido indolbultírico

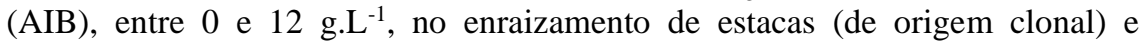
miniestacas (de origem seminal) de $K$. grandifoliola. O experimento foi realizado no viveiro "Mudas Nobres" no município de Goiânia (GO). Foi conduzido em delineamento inteiramente casualizado, em esquema fatorial $5 \times 2$. Foi realizado, também, a aplicação de três modelos (Multivariado, Redes Neurais e randomForest) para estimar o número de brotações nas estacas de origem clonal, de acordo com os dados observados nas miniestacas seminais. Os resultados indicam que o AIB tem efeito contrário nos dois tipos de origem do propágulo, sendo mais indicado para as miniestacas seminais (deve-se aplicar 8 g.L $\mathrm{L}^{-1}$ de AIB) e menos para estacas clonais (não se deve aplicar AIB). Na rotina operacional do viveiro, caso seja recomendado uma padronização de aplicação, a concentração adequada é de 6 g.L. ${ }^{-1}$. 


\section{Introduction}

The use of exotic species has grown, especially in the southern hemisphere, in countries with tropical and subtropical climate (Gomes, 2010). The constant demand for wood and the native forests exploitation made without proper management and even without technical criteria, place high-valuable tree species at risk of extinction. The availability of native forest wood, widely used in Brazil, is in rapid decline and tends to decrease due to severe international restrictions and environmental issues such as global warming (Gomes, 2010). In this context, species of the genus Khaya sp., popularly known as "African mahogany" are currently one of the most profitable hardwoods for investors and rural producers. The production of a higher quality wood in forest stands should be according to the market expectations (Pierozan Junior et al., 2018). Thus, there is a need for the proper choice of species and silvicultural techniques to be employed (Pierozan Junior et al., 2018).

In Brazil, the introduction and cultivation of exotic Meliaceae plants to replace mainly the native mahogany of the Amazon (Swietenia macrophylla King) is widespread and recommended by research and teaching institutions (Falesi \& Baena, 1999; Castro et al., 2008). This is because African mahogany is a species that adapts well to various conditions of climate and soil, thus offering a great financial return over a relatively long period. Studies show the viability and implantation of the species, thanks to the ease of development, resistance, diversification in its use as a final product and easy adaptation in different environments (de Barros \& Pandolfi, 2017). Also, according to Carvalho et al., 2010, this species was introduced in Brazil due to its high resistance to the micro-lepidopteran Hypsipyla grandella Zeller, the main pest of Brazilian mahogany (S. macrophylla).

African mahogany (Khaya grandifoliola C. DC.) is a high sized heliophile tree, reaching 40 meters in height, featured by a brownish-pink wood, currently planted in many regions of Brazil (Reis et al., 2019). The species K. grandifoliola has a broad brazilian introduced genetic diversity, promptly available to be explored silviculturally (Soares et al. 2020). For many years been mistakenly treated as Khaya ivorensis. Recently, researchers have identified the failure to identify the species (Pennington \& Cheek, 2015). However, their seedlings are still traded as $K$. ivorensis, a mistake that, over time, must be repaired.

Cutting is a process of asexual propagation, which consists of the organization of root inducers in the cells of the secondary phloem of the cambium or of the parenchyma of the wood, which becomes initial roots (Agustí \& Fonfría, 2010). According to studies by Xavier et al., 2003, the main advantages for clonal forest species are: i) formation of identical genetically plantings of high productivity and uniformity; ii) high level of improvement of quality of wood and its products; and iii) the multiplication of individuals resistant to pests, diseases and adapted to specific sites, in addition to transfer across generation-to-generation of propagative stand implantations of the additive and non-additive genetic components, resulting in greater gains within the same generation of selection. Going further, Oliveira et al., 2019, attest that it is possible to associate higher volumetric productivity with higher percentages of heartwood, from clonal cutting propagules.

The use of growth regulators in rooting is a widespread practice and, in many species, it makes the production of seedlings via cutting possible (Fachinello et al., 1995). The group of growth regulators most frequently used is that of auxins, which are essential in the rooting process, possibly because they stimulate ethylene synthesis, favoring the emission of roots (Strader et al. 2010). The use of exogenous indolbutyric acid (IBA) is especially suitable to accelerate the rooting process of the cuttings, and the concentrations used vary according to the season, type of cutting and species to be propagated, with a range considered optimal for stimulate this process in forest species (Wendling \& Xavier, 2005).

This work aimed to evaluate the effect of different concentrations of indolbutyric acid (IBA) on the rooting of cuttings (from clonal propagules) and mini-cuttings (from seed propagules) of Khaya grandifoliola C. DC. and also, to estimate the number of shoots for clonal cuttings using simplified models of multivariate linear regression and artificial intelligence (Artificial Neural Networks - ANN and randomForest modeling).

\section{Material and Methods}

Study area

The present work was developed at the Mudas Nobres seedlings nursery (specialized in Kaya sp.), located in Goiânia, Goiás state (GO), Brazil (16 38'30.0"S 4908'57.1"W). The local climate is $A w$ type, according to Köppen (Alvares et al., 2013), with hot and humid climate, with long dry season and average annual rainfall of $1600 \mathrm{~mm}$ concentered in summer stations.

\section{Experimental procedures and data analysis}

To evaluate the influence of the growth regulator indolbutyric acid (IBA), mini-cuttings were obtained of plants derived from seeds, that germinated in plant tubes at a bench, and from these seedlings the mini-cuttings were effectively taken. This bench is usually called as mini-garden.

Plant cuttings, in turn, were achieved from clonal plants, being already more developed plants. After sample collection, the sprouts were stored in boxes containing water to maintain the hydro turgor 
before performing the cuttings and mini-cuttings nursery process.

The cuttings were standardized with $10 \mathrm{~cm}$, and the mini-cuttings standardized with length size between 5 and $7 \mathrm{~cm}$, containing a range of one to two pairs of leaves which were cut in half. After vegetative preparation, the cuttings and minicuttings had their bases immersed in the hydroalcoholic solutions (1:1) of IBA for a period of 10 seconds in concentrations of $0,6000,8000,10000$ and $12000 \mathrm{mg} . \mathrm{L}^{-1}$ (i.e., 0, 6, 8, 10 and 12 g.L. ${ }^{-1}$ ) before being staked in plant tubes with a capacity of $55 \mathrm{~cm}^{3}$, containing as substrate, the mixture of medium vermiculite and carbonized rice husk (in portions of $1: 1 \mathrm{v} / \mathrm{v}$ ).

After 45 days of greenhouse experiment implantation, the evaluation was performed. The variables: Plant Survival (PS), in percentage (considering cuttings and mini-cuttings that maintain green color); Number of Roots (NR); Total Length of Roots (TLR), in centimeters; and Length of the Largest Root (LLR), in centimeters, were considered. Please, check Figure 1 for a better dimensioning of the measurements made.

The experiment was conducted in a completely randomized design, in a $5 \times 2$ factorial scheme (five concentrations of the IBA phytoregulator: 0 (control), 6, 8, 10 and 12 g. $\mathrm{L}^{-1}$; and two cuttings origins: clonal or from seeds). The data, after verification of residual normality, were submitted to analysis of variance (ANOVA) and the means compared by the Tukey (also known as Honestly Significant Difference - HSD) test at the level of $5 \%$ significance probability (5\% of error type I)

We chose to perform ANOVA, instead of linear regression analysis, aiming at statistical tests, due to the non-linearity of all variables along the gradient of IBA concentrations; and also, because we only practiced 6 levels of sequential IBA' treatments.

The number of shoots for clonal seedlings (cuttings) was not measured, so new data were estimated from three statistical models, all using the software R (Team, 2013). For our knowledge: i) Multivariate linear model (' $\mathrm{lm}$ ' function from $\mathrm{R}$ base package; ii) randomForest (Liaw \& Wiener, 2002), with 500 random trees (default argument of the 'randomForest' R function); and iii) Artificial Neural Networks (Fritsch et al., 2016), with resilient backpropagation algorithm (default argument of the 'neuralnet' $\mathrm{R}$ function), using a single hidden layer with 10 neurons. The package 'neuralnet' focuses on multi-layer perceptron. The linear multivariate model was performed as described by the equation below: $y=\beta_{0}+\beta_{1} x_{1}+\beta_{2} x_{2}+\beta_{3} x_{3}+\beta_{4} x_{4}+e$,

wherein, the variable $y$ refers to the Number of Shoots - NS - measured in the seed cuttings; $x_{1}$ to $x_{4}$ refer respectively to: (1) Plant Survival - PS; (2) Number of roots - NR; (3) Length of the Largest Root - LLR; and (4) Total Root Length - TRL, also measured in the seed cuttings; $\beta_{0}$ to $\beta_{4}$ are the linear regression coefficients; and $e$ is the residual of the model. It was not the object of this work to deepen into mathematical and theoretical aspects of the estimation methods via artificial intelligence (randomForest and Artificial Neural Networks), however the dependent variable $(y)$ and the independent variables $\left(x_{1}\right.$ to $\left.x_{4}\right)$ were adopted in the same way as the Linear Model to those two models.

From the three models described above, those applications generated the estimated values of clonal shoots (non-measured data), using data $x_{1}$ to $x_{4}$ effectively measured in the clonal cuttings.

\section{Results and Discussion}

Evaluation of cutting and mini-cutting variables

Seedling production by mini-cuttings is considered ideal when low mortality rates are reached. The rooting phase is when the highest mortality rates for mini-cuttings usually occur (de Oliveira et al., 2015). It was observed that, for the treatments with indolbutyric acid (IBA) evaluated, there were significant differences between the cuttings of clonal origin and the control cuttings, which were not immersed in the IBA solution (Table 1). There was no significant difference, for both, in the sprouting. The variable Length of the Largest Root (LLR) was not significant for cuttings of clonal origin. It is also observed that the number of roots was significantly influenced by different IBA concentrations. The application of IBA aiming clonal propagation of Hymenaea courbaril L. (Moura et al., 2019) and the conifer Araucaria angustifolia (de Almeida Maggioni et al., 2019), also did not provide promising results. Going further, mini-cuttings had greater use of treatments with IBA compared to cuttings from clonal plants, which in this way are more affected towards aging (Figure 1).

The number (NR) and length of roots (TLR) were influenced by the application of IBA only in mini-cuttings of seed origin, and it can be inferred that the degree of youthfulness of the propagules used were efficient in stimulating the emission of roots, probably due to good nutrition of the roots, the presence of leaves and apical buds, good environmental conditions in the greenhouse and the endogenous hormonal balance typical of the minicuttings development. 
Table 1. Mean squares of the analysis of variance (ANOVA) and respective significance by the P-value of the $\mathrm{F}$ test, for treatments of African mahogany cuttings ( $K$. grandifoliola) with indolbutyric acid (IBA), and the Coefficient of Variation (CV) in percentage.

\begin{tabular}{|c|c|c|c|c|c|c|c|c|c|c|c|}
\hline \multirow{2}{*}{$\frac{\mathrm{FV}}{\text { Origin }}$} & \multirow{2}{*}{$\begin{array}{c}\text { DF } \\
2-1=1\end{array}$} & \multicolumn{2}{|l|}{ PS } & \multicolumn{2}{|l|}{ NR } & \multicolumn{2}{|l|}{ TLR } & \multicolumn{2}{|l|}{ LLR } & \multicolumn{2}{|l|}{ NS } \\
\hline & & 4400.1 & $* * *$ & 135.893 & $* * *$ & 8218.9 & $* * *$ & 147.939 & $* * *$ & 0.04728 & ns \\
\hline IBA & $5-1=4$ & 485.6 & $* *$ & 2.609 & $* *$ & 88.5 & $* * *$ & 0.532 & $\mathrm{~ns}$ & 0.09043 & ns \\
\hline Origin $\times$ IBA & $\begin{array}{c}(2-1) \times \\
(5-1)=4\end{array}$ & 465.3 & ** & 4.967 & $* * *$ & 260.8 & $* * *$ & 2.112 & $* *$ & 0.50598 & ns \\
\hline Residual & 35 & 96.5 & & 0.588 & & 6.3 & & 0.469 & & 0.28013 & \\
\hline $\mathrm{CV}(\%)$ & & 12.85 & & 17.81 & & 12.52 & & 13.87 & & 41.88 & \\
\hline
\end{tabular}

FV: ANOVA' Factor of Variation; DF: Degrees of Freedom. Variables: PS: Plant Survival (\%); NR: Number of roots (count); TLR: Total Length of Roots $(\mathrm{cm})$; LLR: Length of the Largest Root $(\mathrm{cm})$; and NS: Number of Shoots (count).

***: significant adopting $\alpha=0.001$; **: significant adopting $\alpha=0.01$; ns: not significant.
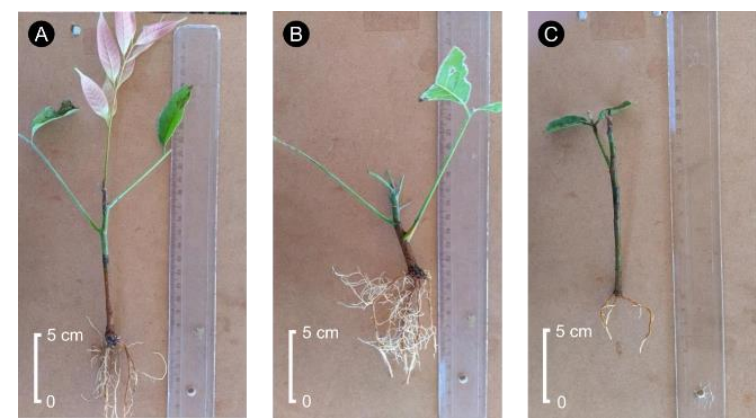

Figure 1. Illustration of three African mahogany $(K$. grandifoliola) cuttings and mini-cuttings treatments. A) Mini-cuttings from seed plants with sprouting, at treatment $8 \mathrm{~g} . \mathrm{L}^{-1}$. B) Mini-cuttings with a large number of roots, at treatment 12 g.L $\mathrm{L}^{-1}$. C) Cuttings from clonal plants with no sprouts and few roots, at treatment $10 \mathrm{~g} . \mathrm{L}^{-1}$.

To highlight the importance of the cutting juvenility, Botelho et al. (2005), evaluating woody, semi-woody and herbaceous cuttings of vine rootstock hybrid of Vitis rotundifolia $\times V$. vinifera L., reporting the obtaining of best rooting response with herbaceous cuttings, reaching $92 \%$ rooting rate, while the woody ones did not take roots. With this, the use of herbaceous cuttings allows to obtain better rooting responses when compared to woody or semiwoody cuttings, as already demonstrated in studies carried out with persimmon (Bastos et al., 2005). New studies conducted with cuttings from younger individuals indicated that it can be the best nursery protocol, as suggested by Fagundes (2013). These results suggest that regrowth cuttings of mothertrees, due to their higher cellular activity, can present greater results.
For the jequitibá-rosa (Cariniana strellensis (Raddi) Kuntze), Castro (2011) also found that the apical cuttings, collected from a clonal garden of seed origin, had greater rooting potential in relation to the intermediate ones, in addition to providing the seedlings with greater mass dryness of the aerial part and the root system. The visual aspect of the roots in mini-cuttings (seed), had better results when compared to the clonal cuttings, in general, as can be seen in Figure 1. As stated by Hartmann et al. (2011), the increased concentration of auxins applied to cuttings, stimulates root induction. Such behavior can be seen in Figure 1-B and numerically at Figure 2, mainly for mini-cuttings.

The number of roots (NR) and the total length of roots (TLR) are very important variables in the production of seedlings, because the more vigorous the root system, the greater the water and nutrient absorption capacity for the seedling, increasing its survival in the field and better post-planting. According to Fischer et al. (2008) the average number of roots per cut and length of the largest root, may be related to the endogenous content of auxin, co-factors and inhibitors in the cuttings, and morphological differences, especially in the dormant material, determined by genetic differences of cultivars.

The IBA has been shown to be more efficient in promoting adventitious roots in cuttings of forest species, given its lower mobility and greater chemical stability inside the cutting. The roots require a minimum concentration of auxins, however high concentrations inhibit their growth. The cells associated with conducting vessels are stimulated by the addition of auxins, cells derived from vessels that grow out of the callus, form the root meristem (Borges et al., 2011). 

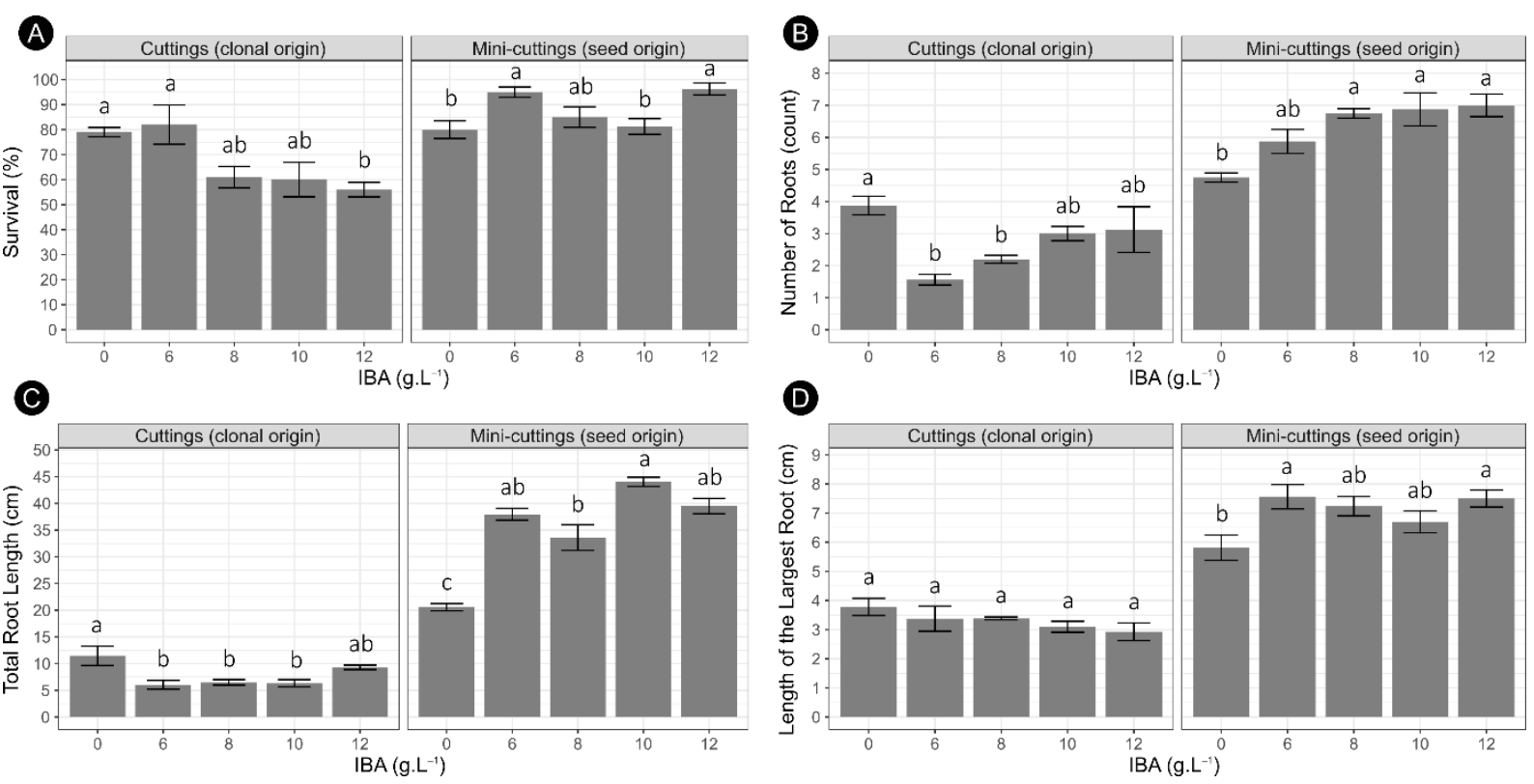

Figure 2. Results of the Tukey (HSD) test (using $\alpha=0.05$ ), in the different measured variables of $K$. grandifoliola cuttings and different Indolbutyric Acid (IBA) concentrations (abscissa axis). A) Plant Survival, in percentage; B) Number of Roots, a count. C) Total Roots Length, in centimeters. D) Length of the Largest Root, also in centimeters.

Evaluating a work with $K$. ivorensis' stem cuttings, the concentration of $2 \mathrm{~g} . \mathrm{L}^{-1}$ of IBA was the one that had the highest rooting rate $(72 \%)$ (Azevedo, 2018). Despite the advances in clonal propagation obtained in different researches, it is necessary to establish optimal conditions for each cultivated species (see Mantovani et al., 2017). For the production of Khaya senegalensis' seedlings, Vasconcelos (2012) observed branch cuttings seedlings success of seed origin, without the use of IBA.

Estimating sprouting of clonal cuttings based on seed mini-cuttings

We can observe some Pearson' correlations among the mini-cutting variables: survival, number of roots, length of the largest root, total length of roots in relation to the number of shoots. We observed a positive correlation $(0.53)$ between the number of sprouts and the length of the largest root. That is, possibly, the greater the length of the root, the greater the number of shoots (Figure 3). According to Ferrari et al. (2004), the shoots obtained may be related to the use of fertigation, the nutritional condition causes physiological changes in the mother plant, contributing to the accumulation of reserves, which can increase the growth of the propagules.

As the sprouts (i.e., cutting shoots) were not measured for seedlings of clonal origin, these data were estimated from three statistical models: Linear Model, randomForest and Neural Networks, with the $\mathrm{R}$ software. The best correlation between the observed and estimated data in the Neural Networks model, presenting $\mathrm{r}=0.96$ (Figure 4 ).
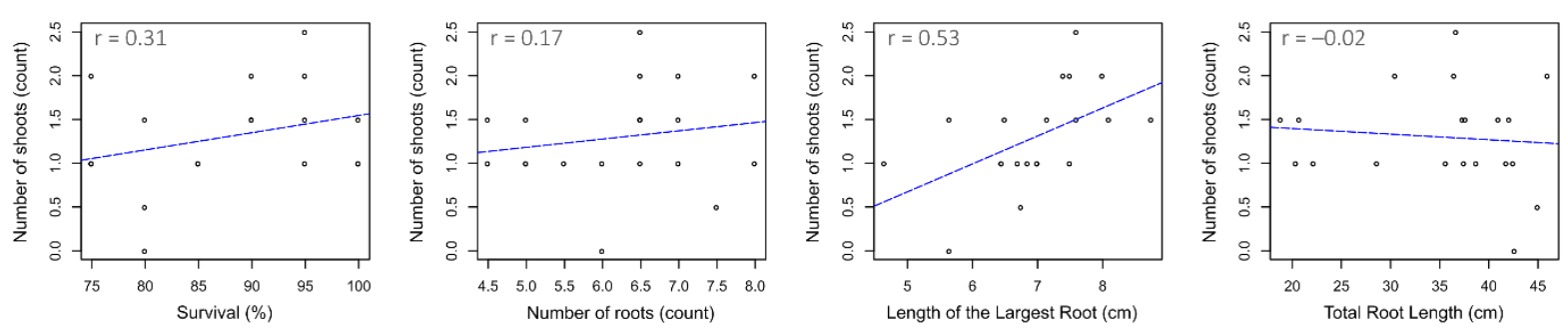

Figure 3. Relationships between Plant Survival, Number of Roots, Length of the Largest Root; and Total Root Length (abscissa axis), in relation to the Number of Shoots (ordinate axis), using exclusively the African mahogany (K. grandifoliola) cuttings from seed plants (mini-cuttings). The presented ' $r$ ' is the linear correlation coefficient. Such relationships were explored in the forecasting models. 

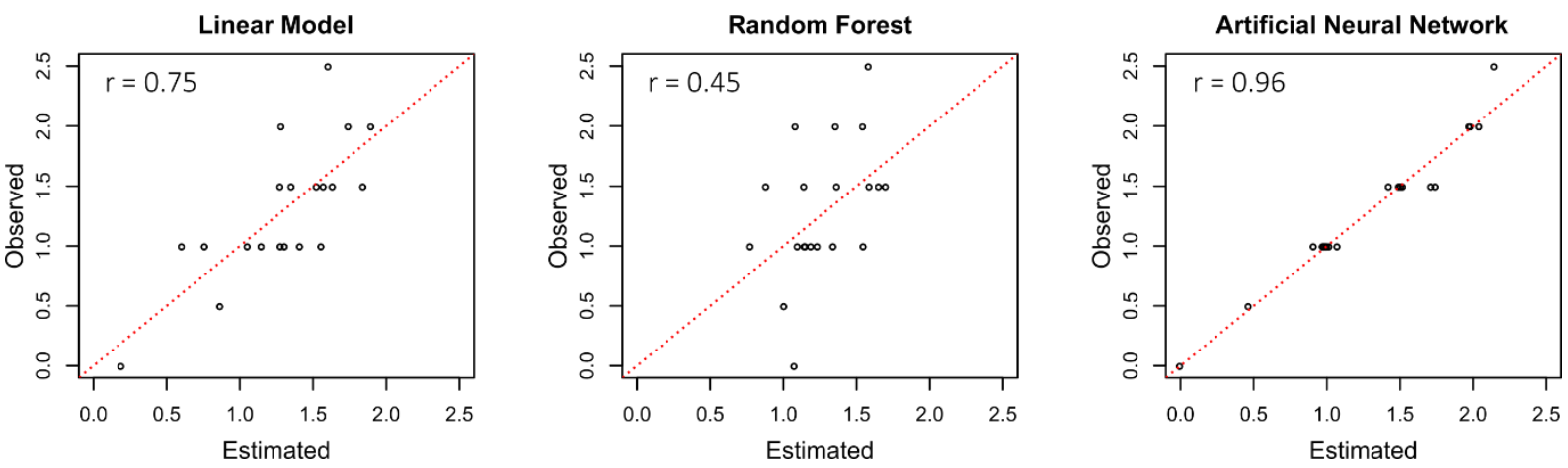

Figure 4. Results of the three types of the training model (Linear; Random Forest; and Artificial Neural Network) aiming forecast the Number of Shoots (NS) in African mahogany cuttings. The mini-cuttings NS estimated is compared with the real number observed (diagonal dotted line). Note that, only mini-cuttings from seed plants were used for all models (i.e., there is both real and estimated data). The ' $r$ ' shown is the correlation coefficient between estimated and observed values.

It is depicted the difference in the number of shoots at different concentrations of indolbutyric acid, in cuttings and mini-cuttings (Figure 5). For cuttings (from clonal seedlings) these data were estimated from the other variables using the neural network model (blue bars). It is also verified that, for the mini-cuttings in the concentration of 12 g. $\mathrm{L}^{-1}$, there was a greater number of sprouts. While for the estimated cuttings data, the different concentrations of IBA did not produce greater results.

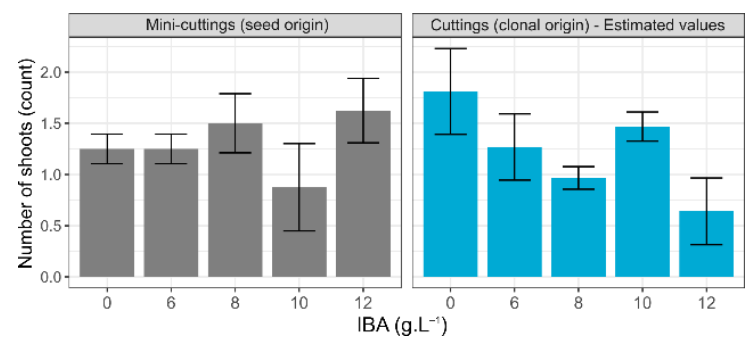

Figure 5. Number of shoots (NS) in mini-cuttings from seed seedlings (left plot) and cuttings from clonal seedlings (right plot), both plot in different Indolbutyric Acid (IBA) concentrations. Data from mini-cuttings of seed plants origin are the real ones (gray bars), i.e., observed values in the experimental field. Data of cuttings from clonal origin are estimated by the Artificial Neural Network (blue bars). See Table 1 to follow those statistical results (at 'NS' column).

The association of phytoregulators may be a comprehensive path, Ferraz et al. (2018) observed for fig-tree (Ficus carica) an improvement in emission and growth of shoots in apical woody cuttings with 2 g.L $\mathrm{L}^{-1}$ of IBA associated with 10 mL.L ${ }^{-1}$ of hydrogenated cyanamide. The same IBA concentration used by Lopes et al. (2003) that verified for the acerola (Malpighia punicifolia L.) emission of shoots in the cuttings after 25, 35, 45 and 60 days after the experiment was set up and showed a positive correlation to the increase in concentration of IBA up to $2 \mathrm{~g} . \mathrm{L}^{-1}$. There was a significant gain in the appearance of sprouts at 25 days due to the increase in IBA concentrations. After 45 and 60 days there was a longer duration of shoots and emission of new shoots. For Rubus fruticosus it showed a decrease in the percentage of sprouting with the increase of IBA concentrations. The cuttings treated with $4 \mathrm{~g} . \mathrm{L}^{-1}$ of IBA showed an average percentage of sprouting (Tadeu et al., 2012).

The results obtained with the use of different concentrations of the regulator between different researched species was already expected, as it is related to the intrinsic characteristics of each one. In relation to the origin of seedling (from seed or clonal), the results of shoots not followed the observed for rooting (Table 1), with the mini-cutting showing better results for the highest concentrations. It presupposes, therefore, that sprouts are also related to the youthfulness of seed cuttings.

\section{Conclusions}

The use of phytoregulator should be considered for seedling production of African mahogany ( $K$. grandifoliola) by mini-cuttings (from seed origin), since this presented promising results with the use of Indolbutyric Acid (IBA), when evaluated survival, root, and sprouts at mini-cuttings variables.

On the other hand, considering cuttings (from clonal origin), in according to the observed values of survival and root variables, and in addition to the estimated values of sprouts, it is not recommended to apply IBA. However, we suggest that is necessary to carry out new evaluations to confirm this sprouting result.

Into a nursery operational routine, if it is necessary to standardize the protocol to IBA application for both clonal and seed origin (cuttings and mini-cuttings, respectively), it is recommended to apply the concentration 6 g. $\mathrm{L}^{-1}$. 


\section{Acknowledgements}

Authors would thank to Prof. Jácomo D. Borges and Dr. Jorge L. S. Ferreira for scientific suggestions; to Forest Inventory Lab. of EA/UFG (Profloresta); to the lab technician Guilherme Murilo; the operational support of the Mudas Nobres seedlings nursery; and the financial support of Coordenação de Aperfeiçoamento de Pessoal de Nível Superior (CAPES), Conselho Nacional de Desenvolvimento Científico e Tecnológico (CNPq), and Fundação de Amparo à Pesquisa do Estado de Goiás (FAPEG).

\section{References}

Agustí M, Fonfría MA (2010) Fruticultura. MundiPrensa Libros.

Alvares CA, Stape JL, Sentelhas PC, de Moraes G, Leonardo J, Sparovek G (2013). Köppen's climate classification map for Brazil. Meteorologische Zeitschrift, 22(6): 711-728.

Azevedo M (2018) Micropropagação e enraizamento de miniestacas de mogno africano (Khaya ivorensis A. Chev). Universidade Federal Dos Vales Do Jequitinhonha e Mucuri (UFVJM). Dissertação. Programa De Pós-Graduação em Ciência Florestal.

Bastos DC, Pio R, Scarpare Filho JA, Libardi MN, Almeida LFP, Entelmann FA (2005) Enraizamento de estacas lenhosas e herbáceas de cultivares de caquizeiro com diferentes concentrações de ácido indolbutírico. Revista Brasileira de Fruticultura, 27(1), 182-184.

Borges SR, Xavier A, de Oliveira LS, de Melo LA, Rosado AM (2011) Enraizamento de Miniestacas de Clones Híbridos de Eucalyptus globulus. Revista Árvore, 35(3):425-434.

Botelho RV, Maia AJ, Pires EJP, Terra MM, Schuck E (2005) Efeitos de reguladores vegetais na propagação vegetativa do porta-enxerto de videira "43-43" (Vitis vinifera x V. rotundifolia). Revista Brasileira de Fruticultura, 27(1): 6-8.

Castro AC, Júnior L., de Brito J, Santos N. de F. A. dos, Monteiro EMM, Aviz MAB, Garcia AR (2008) Sistema silvipastoril na Amazônia: ferramenta para elevar o desempenho produtivo de búfalos. Ciência Rural, 38(8): 2395-2402.

Castro WH (2011) Propagação vegetativa do jequitibá-rosa (Cariniana estrellensis (Raddi) Kuntze) e do pau-jacaré (Piptadenia gonoacantha (Mart.) Macbr.) por estaquia. Dissertação (Mestrado em Ciência Florestal) - Universidade Federal de Viçosa (UFV)

de Almeida Maggioni R, Tomasi JDC, ZuffellatoRibas KC, Wendling I (2020) Araucaria angustifolia: ácido indol butírico e diferentes clones no enraizamento de estacas. Advances in Forestry Science, 7(1): 861-866.

de Barros LAG, Pandolfi M (2017). Viabilidade Econômica Da Produção De Mogno-Africano Na Região Sudeste (Khaya ivorensis). SIMTEC Simpósio de Tecnologia da Fatec Taquaritinga, v. 3, n. 1, p. 10.

de Carvalho AM, da Silva BTB, de Figueiredo Latorraca JV (2010) Avaliação da usinagem e caracterização das propriedades físicas da madeira de mogno africano (Khaya ivorensis A. Chev.). Cerne, 16, 106-114.

de Oliveira TPF, Barroso DG, Lamônica KR, Carvalho VS, de Oliveira MA (2015) Efeito do ácido indol-3-butírico (AIB) no enraizamento de miniestacas de ipê-roxo (Handroanthus heptaphyllus Mattos). Ciência Florestal, 25(4), 1043-1051.

Fachinello JC, Hoffmann A, Nachtigal JC, Kersten E, de Fortes GRL, Hoffmann-Roder A, Kersten E, Fortes GRL (1995) Propagação de plantas frutíferas de clima temperado. Pelotas: UFPEL-Ed. Universitaria.

Fagundes PRO (2013) Propagação vegetativa de mogno africano. Dissertação (Mestrado em Agronomia) - Universidade Federal de Roraima.

Falesi IC, Baena ARC (1999) Mogno-africano Khaya ivorensis A. Chev. em sistema silvipastoril com leguminosa e revestimento natural do solo. Embrapa Amazônia Oriental-Documentos (INFOTECA-E).

Ferrari MP, Grossi F, Wendling I (2004). Propagação vegetativa de espécies florestais. Embrapa Florestas Colombo.

Ferraz RA, Leonel S, Souza JMA, de Souza Silva M, Gonçalves BHL (2018). Enraizamento de estacas de variedades de figueira com o emprego de ácido indolbutírico. Energia na agricultura, 33(1): 81-86.

Fischer DLO, Fachinello JC, Antunes LEC, Tomaz ZFP, Giacobbo CL (2008) Efeito do ácido indolbutírico e da cultivar no enraizamento de estacas lenhosas de mirtilo. Revista Brasileira de Fruticultura, 30(2): 285-289.

Fritsch S, Guenther F, Guenther MF (2016) Package 'neuralnet.' The Comprehensive R Archive Network.

Gomes DM (2010). Análise da viabilidade técnica, econômico-financeiro para implantação da cultura do mogno africano (Khaya ivorensis A. Chev.) na região oeste de Minas Gerais [monografia]. Curitiba: Universidade Federal Do Paraná, 70.

Hartmann HT, Kester DE, Geneve RL (2011) Hartmann \& Kester's plant propagation principles and practices. Prentice Hall. 
Liaw A, Wiener M (2002) Classification and regression by randomForest. R News, 2(3): 18-22.

Lopes JC, Alexandre R, Silva A, Riva E (2003) Influência do ácido indol-3-butírico e do substrato no enraizamento de estacas de acerola. Current Agricultural Science and Technology, 9(1).

Mantovani N, Roveda M, Tres L, Fortes FO, Grando MF (2017) Cultivo de canafístula (Peltophorum dubium) em minijardim clonal e propagação por miniestacas. Ciência Florestal, 27(1): 225-236.

Moura LC, Titon M, Moura CC, Souza CC, Santana RC (2019) Ácido indolbutírico (AIB) e substratos na propagação vegetativa de Jatobá (Hymenaea courbaril L.) por miniestaquia. Advances in Forestry Science, 6(1): 515-522.

Oliveira AC, Pereira BLC, da Silva Mendes MC, dos Santos Lemos JA, Madi JPS (2019) Influência do método de propagação na produção e qualidade da madeira de Tectona grandis. Advances in Forestry Science, 6(3): 761-765.

Pennington TD, Cheek M (2015) Khaya grandifoliola C. DC., http://floradobrasil.jbrj.gov.br/reflora/herbarioVirtu al/ConsultaPublicoHVUC/ConsultaPublicoHVUC. do?idTestemunho=4658185 (20 Apr 2020).

Pierozan Junior C, Patachi Alonso M, Cortese D, Pierozan CR, Walter JB, Cortese D (2018) Viabilidade econômica da produção de Khaya ivorensis em pequena propriedade no Paraná. Pesquisa Florestal Brasileira, 38.

Reis C, de Oliveira EB, Santos AM (2019) Mognoafricano (Khaya spp.): atualidades e perspectivas do cultivo no Brasil. Embrapa Florestas-Livro científico (ALICE).

Soares SD, Bandeira LF, Ribeiro SB, Telles MPC, Silva JA, Borges CT, Coelho ASG, Novaes E (2020) Genetic diversity in populations of African mahogany (Khaya grandioliola C. DC.) introduced in Brazil. Genetics and Molecular Biology, 43(2).

Strader LC, Chen GL, Bartel B (2010) Ethylene directs auxin to control root cell expansion. The Plant Journal, 64(5): 874-884.

Tadeu MH, Pio R, Tiberti AS, Figueiredo MA de, Souza FBM (2012) Enraizamento de estacas caulinares e radiculares de Rubus fruticosus tratadas com AIB. Revista Ceres, 59(6): 881-884.

Team RC (2013) R: A language and environment for statistical computing.

Vasconcelos RT (2012). Enraizamento de estacas de Khaya senegalensis A. Juss. em diferentes concentrações de ácido indolbutírico. Dissertação. Programa de pós-graduação em Agronomia, Universidade Estadual de São Paulo (UNESP).
Wendling I, Xavier A (2005) Influência do ácido indolbutírico e ds miniestaquia seriada no enraizamento e vigor de miniestacas de clones de Eucalyptus grandis. Revista Árvore, 29(6): 921930.

Xavier A, Santos GA, Wendling I, Oliveira ML (2003) Propagação vegetativa de cedro-rosa por miniestaquia. Revista Árvore, 27(2): 139-143. 